InOedia $\begin{aligned} & \text { InMedia } \\ & \text { The French Journal of Media Studies }\end{aligned}$

9.1. $\mid 2021$

Film and TV-induced Tourism: Some Contemporary

Aspects and Perspectives

\title{
"A Magic Beyond All We Do Here": Musical and Sonic Worldbuilding at Harry Potter Tourist Attractions
}

Daniel White

\section{(2) OpenEdition}

\section{Journals}

Electronic version

URL: https://journals.openedition.org/inmedia/2799

DOI: 10.4000/inmedia.2799

ISSN: 2259-4728

Publisher

Center for Research on the English-Speaking World (CREW)

Electronic reference

Daniel White, "'A Magic Beyond All We Do Here": Musical and Sonic Worldbuilding at Harry Potter

Tourist Attractions", InMedia [Online], 9.1. | 2021, Online since 15 January 2022, connection on 08 February 2022. URL: http://journals.openedition.org/inmedia/2799 ; DOl: https://doi.org/10.4000/ inmedia.2799

This text was automatically generated on 8 February 2022.

(C) InMedia 


\title{
"A Magic Beyond All We Do Here": Musical and Sonic Worldbuilding at Harry Potter Tourist Attractions
}

\author{
Daniel White
}

\section{Introduction}

1 Harry Potter has become one of the highest-grossing media franchises of all time, valued at over $\$ 25 \mathrm{bn}$ in 2016 , and this figure continues to rise with the addition of two Fantastic Beasts films $(2016,2018)$ and other forthcoming films in the series. ${ }^{1} \mathrm{~A}$ truly global phenomenon, the novels have been translated into at least 80 languages, and besides two film series the franchise has spawned a variety of other 'in-universe' books by the author J.K. Rowling, an official web outlet, several videogames on a wealth of platforms, a stage production, a studio tour experience, theme park attractions, live concert performances and a vast array of official (and unofficial) merchandise. ${ }^{2}$ There are now so many ways in which a Harry Potter fan can inhabit the wizarding world besides film-watching, and many of these routes into the fantasy world employ music and sound in the world's construction and perpetuation.

2 This article analyses four distinct experiences and attractions related to the Harry Potter franchise: the CineConcerts tours of Harry Potter films performed with a live orchestra, the Warner Bros 'Making of Harry Potter Studio Tour' in Leavesden UK, the 'Wizarding World of Harry Potter' theme park at Universal Studios in Orlando FL, and the WestEnd play Harry Potter and the Cursed Child. The CineConcerts events and the Warner Bros Studio Tour are related wholly to the Harry Potter film series, whereas the Cursed Child play constitutes an extension of the world of the novels, and the Wizarding World in Orlando - though drawing very heavily on the films - also finds inspiration elsewhere in Rowling's wizarding universe. Many of these experiences also feature several forms of possible interaction between guests and the fantasy world. Here, the article focuses specifically on the ways in which music and sound are used to facilitate the guest's 
transition into the worlds and their sustained inhabitation and enjoyment of them. As parts of a pre-existing and transmedial filmic and literary universe, how do these experiences position themselves musically and sonically as extensions of this singular fantasy world? How does music aid our imaginative inhabitation of these fantasy spaces as guests or fans?

In her illuminating study on the advent and future of cinematic special effects, Michele Pierson identifies a desire amongst filmgoers to be tricked or hoodwinked: to be amazed at what they behold by not knowing how it was achieved - in other words, 'a cultural demand for the aesthetic experience of wonder'. ${ }^{3}$ David Butler identifies a similar trend in tracking the origins of the 'fantasy' genre, pointing to the 1920s and 30s categorisation of 'wonder film' to describe audience reactions to films that would now be defined as early fantasy, though Angela Ndalianis traces the wonder of cinema back to (neo-)baroque forms and impulses. ${ }^{4}$ In this sense, wonder is comparable to Tzvetan Todorov's central notion of hesitancy, which hovers somewhere between the uncanny and the marvellous; the sense of wonder arises in the limbo-like space where Todorov locates the essence of fantasy, from a lack of clear or rational explanation to the unanswered question: 'how was it done?'5 Today, the availability of DVD special features and 'making-of' documentaries has given audiences a greater understanding of how films are produced, which arguably generates wonder in a way more akin to the disenchanted enchantment that Michael Saler identifies as a product of modern fantasy. ${ }^{6}$ Going behind the scenes through 'making-of' documentaries or studio tours may simultaneously reveal the artifice of the fantasy world, and yet instil a kind of wonder at the craft of its creation. Music plays an important role in each of the experiences analysed below, which create senses of awe and wonder in different ways, bringing audiences delight without leading them into delusion.

In his book Film Worlds: A Philosophical Aesthetics of Cinema, Daniel Yacavone puts forward a distinction between the 'world-of' a film and the 'world-in' a film. The 'world-in' is the denoted world, built and represented as existing within the film - a notion that is not too far from the traditional concept of the diegesis. This is the world as it is known by the characters, including settings and geographies, creatures and cultures. Yacavone's 'world-of' is the world of the film as experienced by the viewer, which crucially includes meaning, as well as other aesthetic qualities and qualifiers such as 'colour, rhythm, editing, soundtrack etc. " Yacavone clearly demarcates 'soundtrack' as an element of the world-of a film, external to the world depicted within the film and yet still a vital part of the filmic experience. However, Ben Winters puts forward a helpful adjustment to typical understandings of diegetic/non-diegetic music and divides socalled 'non-diegetic' music into 'extra-' and 'intra-' diegetic, the former referring to underscores that exist at a distance from the film-world and its inhabitants, and the latter describing moments where a scene's accompanying music 'exists in the film's everyday narrative space and time'; put simply, moments whose memory may include music when recalled or replayed in the mind of the viewer. ${ }^{8}$ To reflect this distinction back onto Yacavone, music or 'soundtrack' could arguably be theorised as part of the world-in a film (and hence thought of as diegetic, intra-diegetic or meta-diegetic) or of the world-of a film (aligning with Winters' 'extra-diegetic' definition). The fluidity and exportability of film music makes it a powerful agent in applying the aesthetic of the film-world to other non-filmic iterations and experiences such as those analysed 
herein, and these distinctions and terms will aid our understanding of the functions of music in these settings.

What does it mean, then, to create an 'authentic' experience that serves as an inhabitable portion of Rowling's wizarding world, and also as an amusement park, play, museum or concert? These particular attractions are significant because they each offer experiences that are not available through other means of engagement in the world of Harry Potter. Each represents a unique opportunity for fans to access different parts of the story world and to interact with it to varying extents, thus invoking the sense of wonder craved by visitors: the feeling of being somehow part of the world, being included in it and inhabiting it to some degree. Furthermore, the four experiences analysed here can be categorised using a two-dimensional framework set out by B. Joseph Pine II and James H. Gilmore in The Experience Economy. The writers classify forms of engagement in different experiences using two spectra, the first tracking guest participation from passive to active, and the second detailing the type of connection between guest and experience from 'absorption' to 'immersion'. Here, absorption is defined as 'occupying a person's attention by bringing the experience into the mind from a distance' and immersion as 'becoming physically (or virtually) a part of the experience itself. ${ }^{9}$ Plotting these two axes produces four quadrants or realms that Pine and Gilmore use to categorise experiences as 'entertainment', 'educational', 'esthetic' and 'escapist' (see Figure 1). Thus, in the simplest of terms an experience where a guest remains passive and is absorbed at a distance, such as film-watching in a cinema, can be thought of as 'entertainment', whereas a more physically or virtually immersive experience that requires the active participation of the guest is referred to as 'escapist'. Though there are numerous issues with the application of some of these terms (including the negative connotations of 'escapism' that have long been applied to fantasy media) as well as the fact that some experiences may be both immersive and absorptive or fluctuate between active and passive engagement, these categorisations provide a useful way of theorising the different modes of engagement found in the four experiences analysed here. Indeed, each of these can be thought of as operating in a different experiential realm: the CineConcerts film screening can be thought of as passive and absorptive (and thus 'entertainment'); the Warner Bros studio tour as absorptive yet active (and thus 'educational'); the Cursed Child play as passive yet immersive through the use of the whole theatre space (and thus 'esthetic', though perhaps better understood as immersive entertainment); and the Wizarding World theme park as highly active and highly immersive (and thus, for want of a better term, 'escapist').

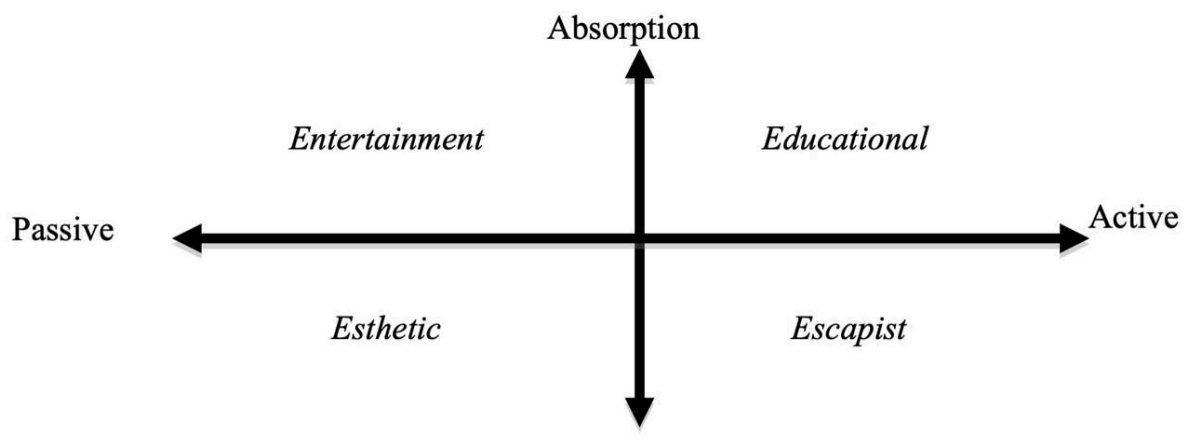

Immersion 
Figure 1 - Pine and Gilmore's Experience Realms

6

Each unique part of the Harry Potter universe draws on the shared wealth of existing material in the films and books, extrapolating or interpolating further information for their own means, and they all intersect in various ways, particularly in their employment of existing or original music which plays an important role in the absorption and immersion of the guest, as well as in their active or passive engagement. The following analyses draw on numerous interviews with sound designers and composers involved in each of the attractions, as well as on fieldwork undertaken by the author, and thus consider both primary and secondary data to understand the use of music and sound in these experiences from the points of view of both the consumer and the producer.

\section{CineConcerts - The Harry Potter Film Concert Series}

Harry Potter is synonymous with excitement around the entire world and we hope that by performing this incredible music with the full movie, audiences will enjoy returning to this world, and to the many wonderful characters and adventures that inhabit it. - Brady Beaubien, Concert Producer. ${ }^{10}$

7 The practice of projecting Hollywood blockbuster films with a live orchestral underscore has become a popular concert format, as well as a way for professional orchestras to recruit larger and more diverse audiences. Jon Burlingame traces the 'live to picture' format back to a performance of Prokofiev's score to 'Alexander Nevsky' by the Los Angeles Philharmonic Orchestra in 1987 (which also served as a reconstruction of the lost manuscript by John Goberman). But it is only recently, with the development of new technologies, that live cinematic concert performances have taken off. ${ }^{11}$ The Lord of the Rings scores have all been performed with live orchestra and chorus since the premiere of The Fellowship of the Ring in Lucerne in 2008, the same year as the first BBC 'Dr Who Prom' (a similarly interactive concert featuring live music to film projection). ${ }^{12}$ However, it is only since June 2016 that Harry Potter fans have been able to experience the films with live music, courtesy of American company CineConcerts and their 'Harry Potter Film Concert Series'. Starting with Harry Potter and the Sorcerer's Stone (the American name for Philosopher's Stone) CineConcerts have now adapted and performed all eight films in the series; at time of writing these orchestral tours have given over 1,300 performances in 48 countries. ${ }^{13}$ This particular film-watching experience provides a new way for fans and audiences to access the fantasy world of Harry Potter, and draws explicitly on music in these processes.

8 Firstly, the Film Concert Series provides a collective experience, as opposed to a more individualised one. Touring large venues and arenas with capacities in the thousands (the author attended a performance of the Philosopher's Stone at Manchester Arena, which has a concert capacity of 18,000), the concert gathers much larger audiences than any conventional cinema in the world. The act of watching and responding to a film with thousands of other people serves to amplify emotional or demonstrative responses among audience members through a phenomenon known as 'emotional contagion'. ${ }^{14}$ Thus, involuntary responses such as laughter, gasping or jumping in fright ripple around the auditorium. Furthermore, an announcement made by the conductor before the beginning of the concert encourages guests not to be a 'well-behaved 
audience' but to 'whoop and cheer for your favourite characters,' and to 'boo and hiss for the bad guys. ${ }^{15}$ These voluntary responses also spread rapidly across the auditorium as the audience are invited to interact with the film - although in truth they are interacting with each other as the cheers and boos form collective responses that unite the audience and tacitly invite everyone to join in. The concerts also enable the collective inhabitation of the wizarding world in the sense that many concertgoers arrive in their official Hogwarts robes (or indeed they purchase some from the many merchandise stalls), with wands and even stuffed owls or frogs. A form of cosplay, this inhabitation (or perhaps cohabitation of wizards and 'muggles' alike) is further encouraged by the conductor who asks 'are there any Gryffindors in the house tonight?!' and goes through all four houses in turn, prompting varying degrees of whooping and cheering. Voluntary and involuntary responses to the film in audiences of such large scale, combined with cosplay and other acts of collective imagining, serve to unify the audience and draw everybody into a collective experience. ${ }^{16}$

9 Music predictably has a much greater prominence here than in an ordinary filmwatching experience. Both the large screen and the large orchestra seated directly beneath it take up roughly the same amount of space in the audience's field of vision. This allows and even encourages a dual mode of viewing, alternating between watching the film and watching the creation of its underscore. ${ }^{17}$ In terms of inhabitation this offers the possibility of a dual inhabitation in the sense that viewers can inhabit the world of the film and the world of the music simultaneously - or perhaps in a state of continual oscillation. The concertgoer's attention need not necessarily be divided, however: one can be engrossed in the film-world and remain aware of the live aspects of the film score, or indeed one can focus on the musicians at work without losing track of the film narrative. This comes in line with Jeff Smith's argument against film music being theorised as somehow 'unheard' or unnoticed. ${ }^{18}$ Not only is film music very clearly heard, here its source is no longer 'unseen'.

Access to the world of the music is further enhanced by supplementary materials: a documentary feature about the music of the film plays as the audience take their seats in the 20 minutes before the film starts, and a programme is available for purchase which includes further information and detail relating to motifs, themes and instruments, as well as a cue-by-cue listing of the concert that enables viewers to follow the track names like symphonic movements. These materials encourage a more direct engagement with the music and provide the audience with access to the finer details of the music's composition, recording and performance. The level of interplay between film and score helps to create a unified experience of the visual and audible domains. The distinct visual separation between screen and orchestra is blurred by the music's synchronisation with the image and its emotive agency as an integral part of the film world - image, sound and dialogue alone would have significantly less emotional impact. As critic Matthew J. Palm writes of CineConcerts, "live music makes Harry Potter even more magical", and there is much truth to this statement. ${ }^{19}$ For many, there is magic in the music - that is, music creates a sense of wonder not only through its affective abilities but also through the mysteries of its production. Many attendees may not be regular concertgoers, or may have little understanding about how orchestras (and indeed their constituent parts and players) create music, and thus the experience of watching and listening to the orchestra may be no less 'magical' than watching the film. Indeed, the magic of one world strengthens that of the other, bringing them together to create a more holistic and wonder-filled experience of the 
film-world. As one audience member wrote, 'the conductor picked up his non-magical wand, signalled the musicians to play, and then I was home'. ${ }^{20}$

\section{Warner Bros. Studio Tour London - The Making of Harry Potter}

11 Opening to the public in March 2012 less than a year after the release of the final film, 'The Making of Harry Potter' Studio Tour in Leavesden UK offers fans a completely different experience of the wizarding world. Still very much related primarily to the film series, the studio tour allows fans to visit the sets and soundstages used in filming, alongside countless props, costumes, models and vehicles. The attraction can host up to 5,000 visitors per day and is predominantly self-guided, allowing guests to move freely between exhibits and even stop off for some lunch or a Butterbeer (a popular wizarding beverage) in the back lot..$^{21}$ It was designed and delivered in conjunction with Warner Bros. by the Los Angeles-based Thinkwell Group.

Music plays a strong role in tailoring the visitor's experience of the exhibits. From the moment a guest enters the building (and even in the car park outside the main entrance) the familiar strains of Hedwig's Theme ${ }^{22}$ and other recognisable motifs drift overhead, underscoring the fan's excitement and beginning the visitor's transition into the world of Harry Potter at the earliest possible moment. The large entrance hall (including ticket offices, gift shop and a Starbucks) is filled with music, though less clearly audible above the animated humdrum of those queuing to enter the exhibits. The music has not simply been chosen at random, however, nor is it all the same - a great deal of time and thought went into designing, creating and mixing the sonic aspects of the exhibition, as carried out by sound designers Vikram Kirby, Kari Rae Seekins and Colbert Davis.

In an interview Kari Rae Seekins detailed the process of choosing and mixing music for each of the exhibits, and she points to the importance of choosing tracks with a sense of wonder.

We had this wealth available to us and that's what the fans would expect to hear the music from the soundtracks. The first step was to go through all of them and actually figure out which music cues could act as background music because a lot of the music, especially as you move into the later soundtracks, is really dark, really dark and doesn't have the same sense of uplifting wonder that the first soundtracks have. For most of the exhibit, almost all of the exhibit, that's the sense that you want the guests to feel, it's that sense of walking into the Great Hall for the first time or discovering the world of magic for the first time. ${ }^{23}$

It is notable that Seekins chose cues not only for their suitability as background music, but for the sense of wonder they contain or create. Seekins and the team selected different cues from all eight soundtracks, making sure no particular themes or tracks were overused, and that each room would have a mixture of cues that suited each location and a long enough loop that guests would not hear the same tracks twice. To this end, the Great Hall (the first room entered on the tour and the only place to which a guest cannot return once they have moved on) was expected to be the place guests would spend the most time, and has a background music (henceforth 'BGM') loop of 70-90 minutes. As Seekins suggests, the earlier soundtracks proved more favourable in 
creating a positive and 'wonder-full' atmosphere, and the positive associations of this music are due in no small part to John Williams's prominent use of melody and motif.

Seekins also went to great lengths to match up certain soundtrack cues and motifs with features of the exhibit with which they were already filmically related, in the hopes of stimulating audiovisual memories for the guests and strengthening the link between the artefacts and guests' memories of them in the films. In this sense music forms a nostalgic bridge, enabling visitors to more easily recollect specific scenes from the 20 hours of film that make up the eight-part series. It is not surprising that Seekins chose a number of tracks from the first of Williams's Harry Potter soundtracks - just as those cues accompanied Harry's (and our) first experience of Hogwarts and the wizarding world, so they continue to underscore the first glimpse of many locations for guests at the studio tour. For example, at the tour's first sight of the Hogwarts Great Hall (which follows an introductory video on a screen that then rises up to reveal the Great Hall doors), the music playing at this point is 'Entry Into The Great Hall And The Banquet' ${ }^{24}$ from Philosopher's Stone, a cue which also accompanied Harry, Ron and Hermione's first glimpse of the very same room (and more accurately our first glimpse of the Hall, the cue being a good example of intra-diegetic music, arguably part of the world-in the film, and though not heard by Harry et al., evoking the sense of wonder felt by both characters and viewers). Similarly, one of the more prominent cues in the BGM loop at Diagon Alley is 'Diagon Alley and the Gringotts Vault'25, also from Philosopher's Stone. Although these cues feature motifs that return only infrequently in Chamber of Secrets, the attention to detail here is likely to reward the most ardent fans with what could be described as the most accurate or 'authentic' experience of these reconstructed locales.

Sound designer Colbert Davis chose a slightly different method when selecting BGM for the 'Platform 93/4' section of the exhibit - a separate room between the main Sound Stage (J) and the back-lot courtyard, which includes a specialist gift shop, several props and a full-size Hogwarts Express train engine and carriage to explore. In collating music for this exhibit, Davis began by taking music from the two longest scenes that take place on the platform: Harry's first visit to it in film one, and the epilogue of film eight that sees Harry returning with his own son. Davis then selected further cues by focussing on the nature of Platform 93/4: 'this is generally speaking a place that's rooted in the muggle world and so I expanded my search to any of the music that I thought was adjacent to the muggle world, or that had something to do with travel'. ${ }^{26}$ The BGM loop for this room thus includes music from eleven tracks including 'The Flying Car' from Chamber of Secrets and 'A Journey to Hogwarts' from Order of the Phoenix, and in fact Davis uses music from every film except Half-Blood Prince. ${ }^{27}$ The effect of this is perhaps more subliminal, again conjuring memories of travelling scenes from the films, six of which feature the Hogwarts Express and five of which do not (see Table 1).

\begin{tabular}{|l|l|l|}
\hline Film & Track & Hogwarts Express? \\
\hline PS & 'Platform 93/4 and the Journey to Hogwarts' & Yes \\
\hline PS & 'Visit to the Zoo and Letters from Hogwarts' & No \\
\hline CoS & 'The Flying Car' & Yes \\
\hline PoA & 'Apparition on the Train' & Yes \\
\hline
\end{tabular}




\begin{tabular}{|l|l|l|}
\hline GoF & 'Another Year Ends' & Yes \\
\hline OotP & 'A Journey to Hogwarts' & Yes \\
\hline DHp1 & 'Obliviate' & No \\
\hline DHp1 & 'Snape to Malfoy Manor' & No \\
\hline$D H p 1$ & 'Sky Battle' & No \\
\hline$D H p 1$ & 'Hermione's Parents' & No \\
\hline$D H p 2$ & 'Epilogue: Nineteen Years Later' & Yes \\
\hline
\end{tabular}

Table 1 - BGM cues in Platform $93 / 4$ and their filmic links to the Hogwarts Express

17 The climactic focal point of the tour and arguably the most effective use of music occurs at the tour's final exhibit, which features a 1:24 scale model of Hogwarts castle used in the production of all eight films. Nearly 50 feet in diameter, the model is in the centre of a darkened room, drawing the eye from every angle of the ramped walkway which surrounds it and which causes visitors to slow down - to stop and marvel at this impressive feat of film craft (see Figure 2).

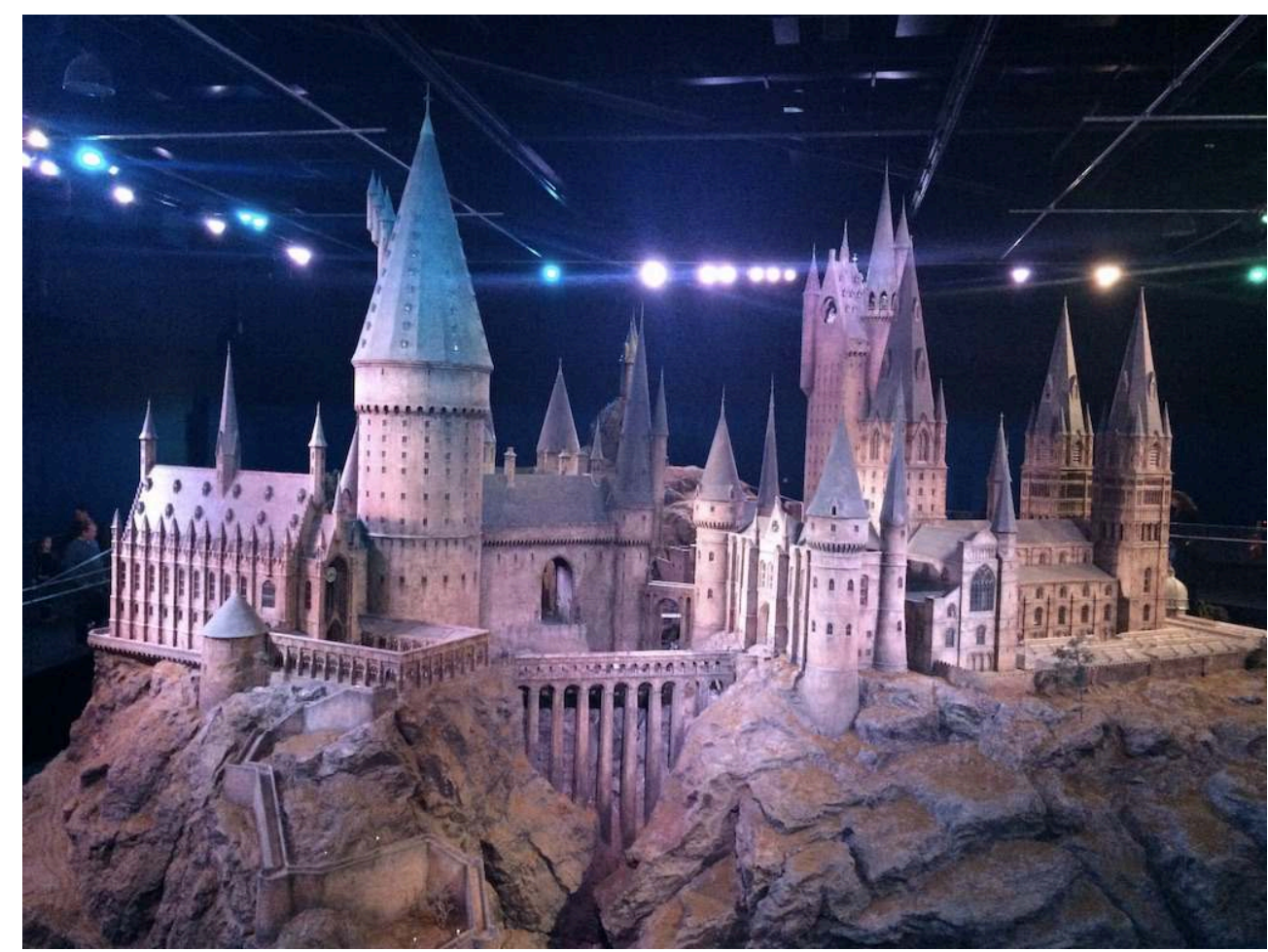

Figure 2 - Hogwarts model with surrounding walkway at Warner Bros Studio Tour.

(C)Daniel White

18 Even the moment a guest first lays eyes on the model of the franchise's primary homespace is perfectly orchestrated, instilling a sense of awe as their eyes adjust to the 
darkness and focus on the immensity and detail of the only lit object before them. One visitor described this moment and its musical accompaniment thus:

There was music playing everywhere in the studios but it was never intrusive and in fact very often well chosen. I thought I'd find it annoying eventually but it really wasn't. It reached a soaring crescendo though when we entered the next room and I became really weepy as we all moved en masse towards the giant (and I mean GIANT) model of Hogwarts Castle. I mean, come on, IT'S HOGWARTS. ${ }^{28}$

19 The music described here by Melanie Clegg consists of a loop of two tracks, also put together by Kari Rae Seekins. The two tracks both come from Patrick Doyle's soundtrack from Goblet of Fire: 'Harry in Winter' and 'Hogwarts Hymn', and were edited by Seekins in order that whatever point a guest hears on first entrance to the exhibit may have a strong emotional effect. ${ }^{29}$

The Hogwarts model, this was definitely about getting the right moment, and wanting people to have a strong emotional moment [...] I remember having to edit the music so that whenever someone steps into this music it can't be at a point in the track where it's not an emotional moment, it has to always be at the point where people feel a strong emotional reaction, so I believe there was some cutting and condensing to make sure it was always on the high notes of the music. ${ }^{30}$

Notably, the two cues (which change in time with the alternation of day/night light effects) appear only in the fourth film, and though 'Harry in Winter' accompanies a snowy scene featuring Harry and Cho Chang, 'Hogwarts Hymn' is heard only over the film's credits. The fact that Seekins chose cues from the more restrained music of Patrick Doyle rather than the more childlike and enchanting cues of John Williams points to the variation in approach identified by Jamie Lynn Webster amongst the scores for the first five films, which has been identified elsewhere as reflecting the maturing tone of the series as a whole. ${ }^{31}$ Rather than being chosen specifically for their extra-musical connotations or encoded meanings, these cues are used wholly for their emotionally affective nature. Furthermore, it is arguable that this emotional climax and centrepiece of the tour is so powerful precisely because of Hogwarts' nature as a (surrogate) home to wizards, witches, film viewers and fans alike.

The Making of Harry Potter is a unique attraction because of the way it invites fans into the world of the films, but also into the world behind it, to see how the fantasy world was constructed: the trickery and artifice behind the movie magic. Michael S. Eddy alludes to this dual inhabitation, "[the tour] brings guests into the experience of making the movies as well as enjoying the fantasy of standing in the middle of the actual Great Hall' ${ }^{32}$ One particular element of the tour brings these two worlds and the inhabitation of them together. Guests are given the opportunity to ride a broomstick in front of a green screen and to watch themselves afterwards on a monitor, now magically zooming through the streets of London with images taken from similar scenes in the films. The consequent personalised film clip is accompanied by assorted recognisable cues, as well as whooshing broom sounds lifted directly from the films' sound design, in the hopes of creating an 'authentic' experience. ${ }^{33} \mathrm{Here}$, as in the rest of the exhibit, music and sound form a bridge between, in theatrical terms, onstage and offstage; between the seen and the unseen - linking the created world with the world of its creation and bringing audiences into both of them simultaneously - or even, again, in a state of oscillation. Hearing a cue from the flying car scene in Chamber of Secrets while standing in front of the very car that appears in that scene draws on musical memory, creating a nostalgic and even uncanny experience - taking 'uncanny' in the Todorovian sense to mean the 
supernatural explained through mechanical means, music conjures the memory of the car's flight while guests are confronted with the truth that it is just, in fact, an ordinary car. Reusing the cue also permanently links the original filmic memory with the new memory of seeing the car up close. Music thus can be seen once again to be drawing tour visitors into the fantasy world by constantly insisting upon its continued existence, even while the world's constructed nature is made apparent. Music stands on the side of the fantastic, turning an attraction that risks the resultant disappointment of seeing the artifice of the world laid bare into an immersive opportunity to see and experience the world as the characters (or actors) did, and further enhancing the emotional impact of standing in the Great Hall or in Dumbledore's office by making it sound just as it does (to us) in the films.

\section{Universal Orlando Resort - The Wizarding World of Harry Potter}

One of the most extensive and immersive opportunities to inhabit the wizarding world takes the form of a theme park, or indeed several theme parks around the globe. Having acquired the licensing rights for Harry Potter-themed amusement parks from Warner Bros in May 2007, Universal Parks and Resorts have since opened 'The Wizarding World of Harry Potter' parks in four locations around the world - first at Universal Studios in Orlando, FL, and consequently at Universal Islands of Adventure (also in Orlando) as well as Universal Studios in Hollywood, CA and in Osaka, Japan. Where the Leavesden studio tour offered fans a look at how the filmic world of Harry Potter was created, the Universal attractions bring this world to life. Visitors are given a chance to walk the wizarding world's (reconstructed) streets, to (buy and) wear wizarding clothes, eat and drink at wizarding establishments, witness performances by famous wizarding musicians, purchase a vast array of wizarding books, sweets and artefacts, and even (with the help of a $\$ 50$ 'interactive wand') do some wizarding of their own by performing magical spells on (some of) their surroundings. As the later additions share many of the same installations, rides and experiences, this article focuses on the two theme parks in Orlando as a case study, comprising the 'Diagon Alley' area of Universal Studios and the 'Hogsmeade' area in Universal Islands of Adventure, the two parks being ingeniously linked by the operative transportation ride 'The Hogwarts Express' (for those with a park-to-park ticket).

In a similar way to the creators of the studio tour, Universal Creative have drawn on music as a key worldbuilding tool in the construction and presentation of their wizarding locations, and as such music from the films is heard on every street, in every shop and on every ride. Music is piped through inconspicuous loudspeakers at ground level or overhead, and the BGM loops include music from all eight films, though the music of the earlier films is once again favoured over that of the later ones - perhaps because the darkening nature of the later soundtracks, as noted above by Kari Rae Seekins, is at odds with the joyful, uplifting ambience intended by the park's designers. To give an example, the Diagon Alley area at Universal Studios contains at least five (though probably more) distinct music loops in different areas: the London street (including Kings Cross Station, 12 Grimmauld Place and the Knight Bus), Diagon Alley itself (in the street and in most shops), Knockturn Alley, inside the Leaky Cauldron pub, and inside Gringotts bank. These loops feature very little crossover of cues between 
them and have been conscientiously chosen for their specific locations: the street in London features part of Nicholas Hooper's theme for Dumbledore's Army from Order of the Phoenix, an exciting major-key theme with a lively semiquaver string ostinato that makes it suitable as one of the first cues heard by those about to enter Diagon Alley. ${ }^{34}$ Another excerpt in this location is 'Wizard Wheezes', a big band piece also by Hooper that not only sits well within the muggle world of London but also corresponds to John Williams's jazz-inflected accompaniment to the Knight Bus (a replica of which is found on the London street) in Prisoner of Azkaban. ${ }^{35}$ Once inside Diagon Alley, a longer list of cues includes many of the most recognisable motifs more commonly associated with the wizarding world and Harry's experience of it ('Harry's Wondrous World', 'Fireworks', John Williams's Love/Reflection theme and of course Hedwig's Theme). The importance of the melodic motif comes to the fore here. These motifs are powerful not only through their associations and connotative abilities but also through their sonic audibility: when approaching a new area of a theme park, the first musical element that can be heard in the air is not the backing, the texture or even the instrumentation, but the melody.

There is one section of the Diagon Alley area that makes use of darker and more sinister cues from the later films, and that is Knockturn Alley: an adjoining street to Diagon Alley that includes 'Borgin and Burkes' and other shops renowned for selling objects of dark magic. This street is visually much darker and more foreboding than its bright and cheery surroundings, and features cues such as Hooper's 'Dumbledore's Farewell' (Half-Blood Prince) and Alexandre Desplat's 'Severus and Lily' (Deathly Hallows Part One) ${ }^{36}$ These tracks are in minor keys with chains of leaning suspensions and are more heavily string-dominated in terms of orchestration. Further cues such as 'Harry and Hermione' and 'Snape and the Unbreakable Vow' (both from Half-Blood Prince) create suspense with long tonic pedals on cellos and basses, violin tremolos, and repeated ostinati on harp or celeste, again in minor keys with some more chromatic suspensions. ${ }^{37}$ There is no crossover between the BGM at Knockturn Alley and the rest of the attractions, and the darker music seems to have been chosen for aesthetic reasons rather than conceptual or associative ones. Neither of the cues from the Knockturn Alley scenes in Chamber of Secrets and Half-Blood Prince are used - instead designers have chosen cues with dark/sombre moods but without any suggestions of threat or danger, and thus aesthetic potency seems to overrule conceptual association. The cues clearly evoke memory and emotion, but on a more affective level than a semiotic or leitmotivic one. Thus, memories of Snape making the unbreakable vow, of the revelation of Snape's enduring love for Lily, or indeed of Dumbledore's death, may invade an informed guest's experience of the space, but rather than causing any cognitive dissonance would more likely add subtle detail to the melancholic, dark yet unthreatening atmosphere. Knockturn Alley is visibly and musically differentiated from its neighbouring street, and in this way the music helps to create a micro-world or 'world within a world', motivically related to Diagon Alley and yet aurally distinct and separate.

The sound designers behind Diagon Alley (and Hogsmeade at Islands of Adventure) relied not only on music's inherent affect in building these distinct worlds, but also on the established links between the music and the world in ('world-in') the films - which is on the whole the world that the park designers have attempted to recreate (as opposed to the world in the books). For example, the loop that plays through the streets of Hogsmeade includes the following cues: 'Hedwig's Theme' (Philosopher's 
Stone), 'Harry's Wondrous World' (Chamber of Secrets), 'Hagrid the Professor' (Prisoner of Azkaban), 'Potter Waltz' and 'Harry in Winter' (both Goblet of Fire). All of these cues have established filmic connections with Hogwarts in some way, which is apt because the village of Hogsmeade at Islands of Adventure sits in the shadow of a large model of Hogwarts Castle, a full-scale building that houses the ride 'Harry Potter and the Forbidden Journey' (see Figure 3). The first two of these cues feature heavy use of the second half of Hedwig's Theme which is established as the primary motif for Hogwarts in the earlier films through its repeated use with aerial or establishing shots of the castle. The next two cues are related to Hogwarts through location - both are used exclusively within the Hogwarts building and grounds. Lastly, 'Harry in Winter' is used not only for establishing shots of Hogwarts in Goblet of Fire, but is also one of two cues used in the Hogwarts exhibit at the Leavesden studio tour, as mentioned above. This cue and the 'Potter Waltz' both relate filmically to images of snow and ice, finding a further point of comparison in the snow-topped roofs of Hogsmeade. Thus, the BGM tracks within Hogsmeade are well-chosen, each serving to add to the atmosphere not only in purely aesthetic ways but by drawing on cinematic memories of filmic shots of Hogwarts, or even on memories of seeing the Leavesden model of the castle in the case of the more committed Harry Potter tourists. ${ }^{38}$ This web of interrelated musical cues and filmic memories, as with the Knockturn Alley music, draws fans into the worldbuilding process, enabling subjective identifications and creating an individualised experience that increases with a fan's knowledge and awareness of the musical world(s) of the films.

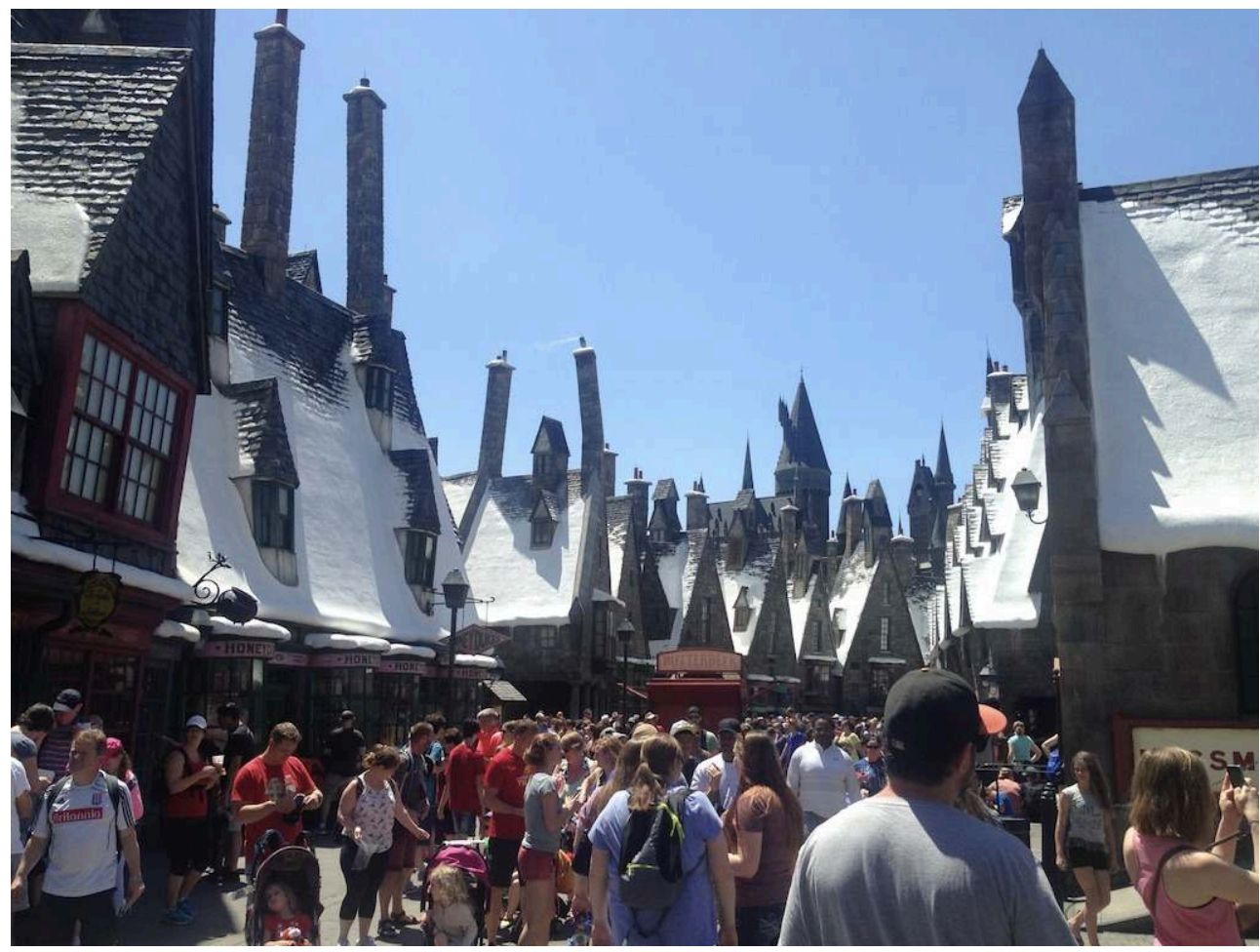

Figure 3 - Snowy Hogsmeade and Hogwarts Castle at Universal Studios, Orlando FL.

(c)Daniel White

Each of the immersive rollercoasters in the Wizarding World of Harry Potter provides further evidence of the reliance on music's links to filmic events or franchise-specific 
conventions. The two Orlando parks each include one indoor rollercoaster or 'motionbased dark ride' which acts as the primary attraction ('Harry Potter and the Forbidden Journey' and 'Harry Potter and the Escape from Gringotts') as well as the Hogwarts Express which doubles as a people-mover and attraction, linking Kings Cross station at Universal Studios with Hogsmeade station at Islands of Adventure. All three of these rides feature the use of music and specially recorded films alongside movement to create a new, immersive experience, with the two rides also including physical sets, wraparound projection, pyrotechnics, and (on 'Escape from Gringotts') 3D visual technology. Soundtracks for the rides are continuous from start to finish, drawing on recognisable musical motifs from the films as well as using original cast members and matching sound design for spells, broom effects, the Gringotts intruder alarm, and so on. ${ }^{39}$ Shorter, simpler motifs lend themselves well to the intense nature and quick pace of the rides, and thus one key theme used in both ride soundtracks is one of John Williams's motifs for evil. The simplest of Williams's three themes for evil and mystery, this chromatic three-note outline is referred to by Jamie Lynn Webster as the 'Something's Odd' motif and is used plentifully throughout the first two films to allude to the presence of evil or darkness. ${ }^{40}$ Its use in the rides acts as a form of musical shorthand for threat and danger, and its simplicity paired with the earlier films' more childish nature gives the threat of the rides a less serious, more caricature-like tone. A similarly simple and effective trope is employed to provide the musical finale to both rollercoasters. Both 'Escape from Gringotts' and 'Forbidden Journey' finish with an extended rendition of John Williams's 'Love/Reflection' theme, which also finishes three of the eight films (Philosopher's Stone, Chamber of Secrets and Deathly Hallows Part Two). ${ }^{41}$ This particular cue is used to signal the end of the ride as the cars return to the safety of the station by drawing on the cue's cinematic codification, using repeated perfect cadences and drawn-out ritardandos to inform guests of the impending end of the ride, and tying up the narrative while guests physically detach themselves from the ride apparatus.

The Hogwarts Express ride not only allows guests to be transported from park to park in a full-scale replica of the train, complete with six-person compartments, but also provides ride-style entertainment via video screens at the windows on both sides of the carriage and in-built surround-sound systems. The ride tracks the journey from London to Hogsmeade (or indeed the return journey), encountering various characters and locations from the films along the way, and lasts approximately four minutes. The musical soundtrack, as was the case for 'Escape from Gringotts', features music from several of the films, specially re-arranged by a team of composers (Jerome Leroy, William Ross and Alex Kovacs) and recorded by the London Symphony Orchestra at Abbey Road studios, the same personnel and setting as the original soundtracks. This music is taken exclusively from John Williams's scores, with one exception - the use of Hooper's 'Fireworks' cue to accompany the broom-riding Weasley twins and their business-promoting firework display. Again, Williams's music here represents the essence of the original, wondrous and more childlike world of Harry Potter, and it is notable that William Ross has a great deal of experience working with John Williams's music, particularly having arranged much of his music for the Chamber of Secrets score. Great care and detail went into matching musical cues to their visual counterparts: the flying car, the spiders, the Knight Bus, Hagrid and Buckbeak are all accompanied by their respective themes. Similarly, the appearance of Hogwarts is supported by the now tropified use of the second part of Hedwig's Theme, as any ardent fan would expect. 
Moreover, Leroy and Ross extrapolate further material from the musical world by altering and adapting numerous Williams motifs, either to flow more smoothly into each other or to reflect the ride narrative - all in keeping with Williams's established compositional style and vernacular. For example, the 'Christmas at Hogwarts' music that plays as the train follows Hedwig through the streets of London is repeated and transposed into the tonic minor key, coinciding with the moment that death eaters appear in the sky and Harry says 'it's getting dark out there' (see Example 1). ${ }^{42}$ The extension and extrapolation of musical material from this world shows both a respect for the composer and the sound world he created, and a dedication to the world's musicological and audio-visual coherence.
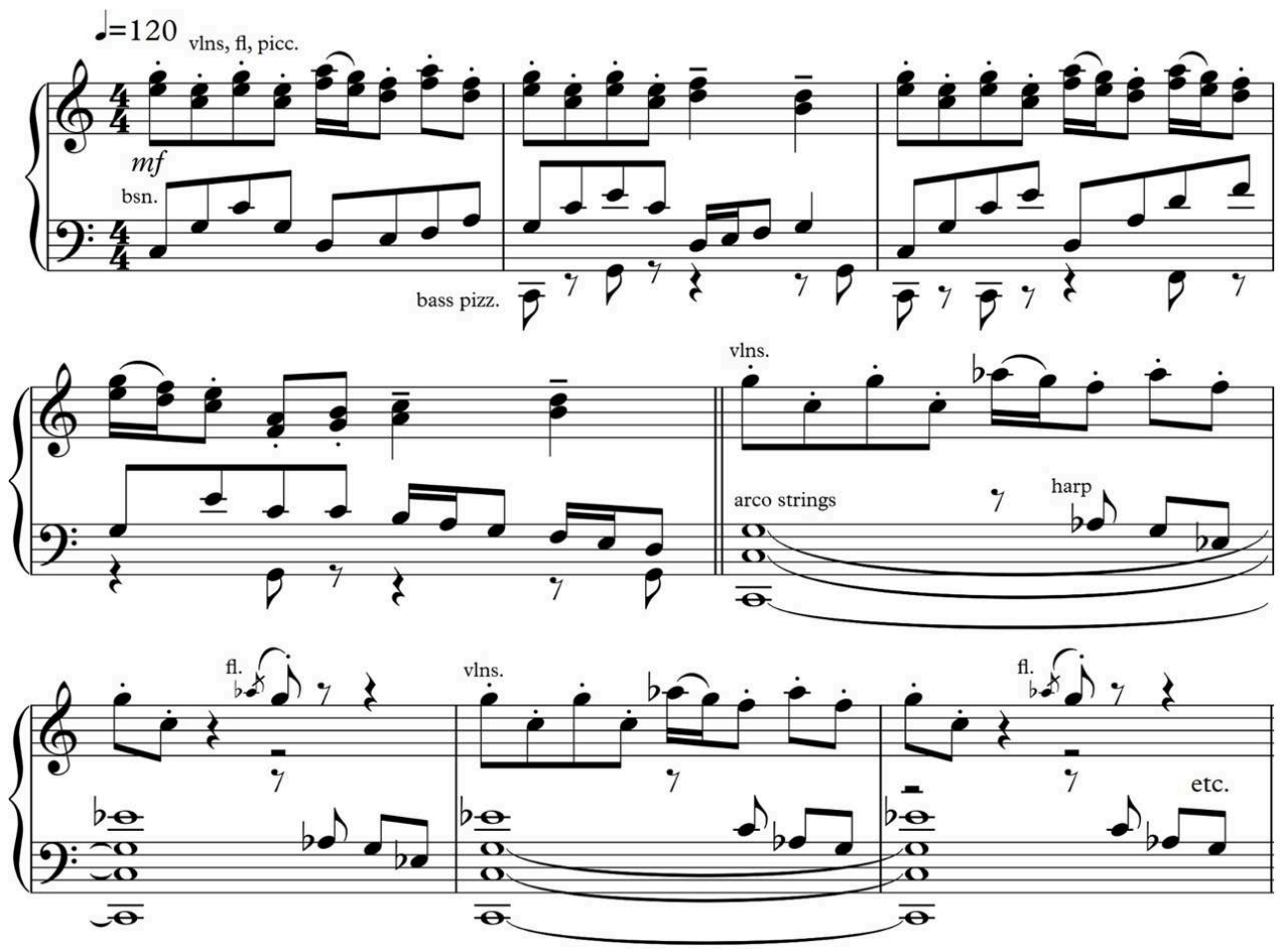

Example 1 - 'Christmas at Hogwarts' and its minor transformation on the Hogwarts Express (author's transcription)

Besides all the music that appears on the streets and rides of the Wizarding World of Harry Potter, there are also several live performances that take place in each of the parks, providing a more 'diegetic' way into the inhabitation of the wizarding world through the performance of its music by 'real' witches and wizards. Two of these performances, the 'Triwizard Spirit Rally' and the 'Tales of Beedle the Bard', involve storytelling or dancing to pre-recorded (and pre-existing) music, but two others, the 'Hogwarts Frog Choir' and 'Celestina Warbeck and the Banshees', feature live singing. The first of these takes its inspiration from a scene in Prisoner of Azkaban that depicts a Hogwarts School Choir performing the John Williams song 'Double Trouble', complete with several instrumentalists and a chorus of giant singing frogs whose tuned croaks and belches provide a curious bassline. The Wizarding World version of the choir features four singers, one presenter and conductor, and between two and four singing frogs held and puppeteered by the singers. Performances last around ten minutes, and include the aforementioned 'Double Trouble' as well as a cappella renditions of the more well-known film themes ('Fireworks' and 'Hedwig's Theme'). Although the 
musical material is mostly drawn from the film music, a few other original (and even comedy) compositions feature, and the singing style is closer to that of the contemporary a cappella group Pentatonix, the TV show 'Glee' or the singing style of the Pitch Perfect films. Here, the concept from the film world of a Hogwarts school choir is extrapolated and mixed with other aspects of contemporary pop culture to create something new, which relates both to the world of Harry Potter and to the musical tastes of many of the park's visitors. The alteration of recognisable Potter music into a more contemporary style, performed by 'Hogwarts' students in school robes, is an interesting example of musical worldbuilding within the park. If High School Musical were set at Hogwarts, this is what it would sound like.

The Motown-inspired performance of Celestina Warbeck and the Banshees is interesting in that the concept is drawn from J.K. Rowling's books rather than the films. First mentioned in the Chamber of Secrets book, the name of the 'popular singing sorceress' was heard by Harry in an announcement on the Weasleys' radio, and she is mentioned several more times throughout the novels as one of the most popular magical musicians within the wizarding community. ${ }^{43}$ That said, she is neither seen, heard nor mentioned in any of the films, and thus her inclusion in the Wizarding World at Diagon Alley points not to a simple recreation of the world-in the films but to a manifestation of the world-of the franchise, drawing on all available information from the canon. Some of this information comes through canonic mentions of the singing sorceress, but much more detail regarding Celestina's appearance, musical style and even lyrical content was provided by J.K. Rowling through her online web outlet, Pottermore. ${ }^{44}$ Here, Rowling states that she 'always imagined [Celestina] to resemble Shirley Bassey in both looks and style', and thus the Universal park designers have followed these suggestions by casting a black singer, in a floor-length sequined dress complete with feather boa. Lyrically, the four songs in Celestina's set describe life, love and loss from the perspective of a showbiz witch, and though musically unrelated to the orchestral cues heard throughout Diagon Alley, the songs, with lyrics written by Rowling herself, represent an 'authentic' and canonic musical expression of the wizarding world.

The notion of authenticity is problematic when it comes to the recreation of a fantasy world that is predominantly film-inspired but existent in other media, particularly when it comes to sound and music. In the NBC documentary 'Harry Potter: The Making of Diagon Alley' which details the two-year process of building the park, the word authenticity comes up several times: 'we are authentically recreating what was seen in the films and what was described in J.K. Rowling's fiction' (Alan Gilmore, Art Director); 'the goal is authenticity, and the bar is set very high' (Meredith Vieira, presenter). ${ }^{45}$ What does it mean, then, to create an authentic experience of Rowling's wizarding world that doubles as an amusement park, and how is this authenticity attempted or achieved? Clearly park designers have drawn on both live performance and the adaptation of soundtrack cues in order to flood guest's ears with the recognisable sounds of the film world. Thierry Coup, Senior Vice President of Universal Creative, best sums up the desired resultant experience in the aforementioned documentary: 'music brings emotions together - even if you close your eyes and you just hear the music of John Williams from the Harry Potter movies you start visualising and you start experiencing and feeling these moments that Harry Potter lived' ${ }^{46}$ Thus, the use of music throughout the streets, shops and rides of the park aims not only to enable fans 
to inhabit this fantasy world and experience its magic, but also to engender identifications with Harry and his friends - taking them one step closer to becoming Hogwarts students or residents of Hogsmeade.

This highlights a subtle yet important distinction: The Wizarding World of Harry Potter does not aim to create a fully coherent fantasy world, but a film-world. In other words, to return to Daniel Yacavone's bifurcation, Universal have for the most part attempted to create the world-in the films, rather than the world-of the films. The experience is not one of complete autonomous freedom in exploring the expansive world-of the films, but rather one of experiencing the more familiar world-in the films: the guest simultaneously directs and stars in their own Harry Potter production within the confines of the (re)created filmic spaces. This aligns with Waysdorf and Reijnders' theorisation that the park represents 'a scripted space rather than a set one [...] scripted spaces create a sense of narrative centered around the walker, one with the illusion of agency' ${ }^{47}$ Although some fans will do all they can to create for themselves as authentic an experience of the wizarding world as possible, by dressing in wizarding garb, learning the spells and buying the drinks, there will always be some immersive limitations: the interactive wands can only cast certain spells in certain places, and the shops still trade in US dollars rather than Galleons, Sickles and Knuts (wizarding currency). Guests are therefore guided towards the things they can do by the enchanting Hamelin-esque music that is piped in to lead the way. Music is one of the only elements of the cinematic 'world-of' that is present in the park's recreated 'worldin', and thus it plays a highly narratological and directional role, acting (to use Winters' terminology) intra-diegetically to influence our actions as visitors (as it does film spectators) and to heighten our sense of characterisation as actors in the play. Gregory Camp presents a similar theorisation in his analysis of music at Walt Disney World by positing a 'double diegesis' where music is positioned as a nodal point between one side of the world controlled by the visitor as protagonist in their own filmic experience, and the other controlled by the 'Imagineers' (park designers) to influence the consumer's every move and monetary investment. ${ }^{48}$ The evidence presented here exemplifies this double diegesis in action, with music crossing and blurring diegetic boundaries to powerful effect.

Music is perhaps the least 'realistic' element of the Wizarding World themed areas in that the well-loved film characters would never have heard Hedwig's theme drifting down Diagon Alley (except for one interesting moment in Philosopher's Stone where Hagrid is seen playing the tune on a recorder), and yet it is vital in the successful portrayal of these spaces as authentic. Waysdorf and Reijnders state that " $t]$ hose visiting know it is a simulation but it becomes an authentic environment when it feels correct on all sensory levels', and thus the inclusion of film music arguably creates a more fantastic/less realistic but no less 'correct' experience of the film's world. ${ }^{49}$ This also aligns closely with Winters' argument for intra-diegetic music being that which becomes very much a part of the film's fabula, thus existing in the everyday narrative space depicted, even if not consciously attended to by the characters. ${ }^{50}$ Here in the park, we hear the music because that is exactly how we remember Hogwarts/Diagon Alley. Camp argues that it is the double diegesis - simultaneously controlling and being controlled - which makes the theme park experience so enjoyable for visitors willing to submit to the fantasy, perhaps via Michael Saler's notion of the 'willing activation of pretence' ${ }^{51}$ Experiences such as choosing a wand (or having a wand 'choose you') at Ollivander's wand shop, drinking a butterbeer or flying on a broomstick - all reinforced 
by joyful and enchanting cues from the films' soundtracks which, importantly, correspond to matching scenes - reduce every guest to their eleven-year-old selves, being introduced as Harry was to the wizarding world for what feels like the very first time; and yet finding it familiar, inviting, and just how they had hoped or imagined.

\section{Harry Potter and the Cursed Child - West-End Play}

33 The most recent addition to the Harry Potter canon is the Cursed Child play, which opened at the Palace Theatre in London's West End in July 2016 and has since opened on Broadway and in Melbourne, San Francisco and Hamburg. The plot was conceived by J.K. Rowling, John Tiffany and Jack Thorne who also wrote the script, and tells the story of an older Harry and his friends whose children are now at Hogwarts, in an adventure that sees the familiar characters facing threats both old and new. Although the play is not a musical, music and sound both play very strong roles in building and portraying the world of the play and, in contrast to the other three case studies in this article, Cursed Child marks a significant departure from the reliance on pre-existing film music. The musical score for the play was written by pop musician Imogen Heap and arranged and compiled in collaboration with the play's music supervisor Martin Lowe. Although mostly unrelated to the existent film scores, music and sound (designed by Gareth Fry) both build a cohesive world for the play in ways that are not dissimilar to the films' music and sound design.

The play is divided into two parts, each lasting around two and a half hours (with interval) and often viewed on consecutive nights or on the same day in matinee and evening performances. The length of the play and its division into four acts puts an added weight on the recognisability and coherence of the play's aural (and visual) world. In other words, the transitions an audience makes in repeatedly departing and re-entering the world of the play must be facilitated and quickened, to aid the recollection of the narrative and indeed the cohesion and effectiveness of the play as an immersive dramatic experience. As a collective attraction, emotional contagion is also at play here as audiences gasp at the magical trickery they witness or shriek at the dementors (dark, ghoulish figures) that invade the auditorium. These audible reactions enable and increase a spectator's immersion in the play-world by engendering, authenticating and affirming equivalent responses. Much of the 'magic' of the play is found in the special effects that make the day-to-day sorcery of the play-world seem so real, and the audible astonishment of the audience renders this magic at once more real and more impossible: we saw it happen, but we do not know how it was done - the supernatural unexplained, the definition of Todorov's 'fantastic'. Lastly, where film is rigid and unresponsive to the viewer, theatre as a medium allows for a degree of interaction between the viewer and the play, where audience reaction and emotion can affect the rhythms and pace of the actors, or actors can break the 'fourth wall' for comedic effect. All of this adds to the immersive nature of the performance.

Sound is used significantly at the start of each act as pre-recorded announcements by four different characters signal the beginning of each half before the house lights are dimmed and the play begins or continues. These announcements are made from the play-world and in character: the opening of Act I takes the form of a train station announcement (in keeping with the suitcase/trolley-laden mise-en-scène), instructing spectators that their 'journey is about to start' and reminding them to switch off their 
phones as they are seated in the 'quiet zone'. Similarly, Act III is introduced by the voice of Professor Umbridge, who again urges spectators to switch off their phones or 'face painful consequences', all the while ushering the audience back into the sinister alternative present which concluded Act II. These announcements represent sonic bridges that reach out from the world of the play into the theatre auditorium and draw the audience in, through both narrative content and the recognisable timbre of each voice (which, in the case of Professor Umbridge, takes clear inspiration from Imelda Staunton's filmic portrayal of the character).

Music plays a strong role in defining and characterising the world of the play, featuring prominently under all scene changes, transitions and important narrative moments, as well as scenes with minimal dialogue. The score itself includes some original material, but is mainly compiled from instrumental versions of songs in Imogen Heap's back catalogue, which have been adapted and rearranged by Heap and Martin Lowe. Notably, the musical aesthetic bears little resemblance to any of the film soundtracks, creating a very different sound-world: largely diatonic, featuring electronic instruments, pads and drum machines, and with a strong, quasi-minimalist rhythmic drive. That being said, it is not too difficult a stretch to see Heap and Lowe's score as an extrapolation or indeed continuation of the journey of Harry Potter soundtracks from John Williams (Philosopher's Stone, Chamber of Secrets and Prisoner of Azkaban) to Alexandre Desplat (Deathly Hallows Part One and Part Two): the latter of which do feature greater use of rhythmic ostinati and are much more diatonic when compared to Williams, Doyle (Goblet of Fire) and Hooper (Order of the Phoenix and Half-Blood Prince). This point of conjecture is reinforced by one further similarity that provides the strongest link between the two musical worlds: the use of wordless female voice. Alexandre Desplat's introduction of 'Lily's theme' in Deathly Hallows Part Two is the first and only instance of a Harry Potter composer using solo voice. ${ }^{52}$ The minor diatonic theme, which comes to represent not only Harry's mother's love for him but also Severus Snape's love for Lily, is sung on an 'ah' sound by the pure, childlike voice of Japanese singer Mai Fujisawa. Most of the Cursed Child score features Heap's voice in a melodic capacity, the vast majority being wordless with 'ah' or 'ooh' sounds. This link is strongest during a scene in which Snape conjures a Patronus charm (a protective spell with the appearance of a ghost-like guardian animal) that takes the shape of a doe - understood by fans to be the same as Lily's, also depicted in Deathly Hallows Part Two. This whole scene is underscored by female voices, shrouded in reverb, singing in the Aeolian mode - the same mode as 'Lily's theme' (this particular cue is entitled 'Expecto Patronum' in Suite Three of the official soundtrack release). ${ }^{53}$ These similarities, even if accidental, provide a strong musical link for spectators to draw between Desplat's world and Heap's, a link strengthened by the fact that the play temporally follows the 'Nineteen Years Later' epilogue of the final film.

With regards to sound, the Cursed Child sound design differs in many ways from that of the films, but in a similar way to the music, one or two similarities form potential sonic bridges for the audience to draw the film and play worlds together, or more specifically, to bring memories of the former into their experience of the latter. One of these is the voice of Voldemort (whose name, incidentally, is pronounced without the final ' $t$ ' in the play - another subtle difference from the films), which whispers 'Harrryyy Pottterrr' several times throughout the play. At these moments, the sound is dispersed from all around the auditorium, thus creating the effect of a disembodied voice: a theatrical acousmetre. Firstly, the strained vocal quality, duration and reverb of 
these utterances are identical to those that Harry hears in the last four films of the franchise as Voldemort (voiced by Ralph Fiennes) establishes and exploits the psychological connection between them. Secondly, an audience that is undoubtedly familiar with this filmic trope will not only recognise the threatening voice of Voldemort instantly, but will also fail to locate the source of the sound, with the voice coming at them from every direction - as close as the sound designers could get to placing a voice inside the audience's heads. This particular meta-diegetic sound is clearly heard by Harry but not by other on-stage cast members. In this way the audience is encouraged to form stronger subjective identifications with Harry through the shared experience of his psychological turmoil.

The stark differences between the music and sound design of the Cursed Child play and the franchise films were clearly intentional, the play putting together something new and original in these respects, yet still considering itself to be part of the same narrative universe. The decision to bring Imogen Heap into the project as a composer was made primarily by movement director Steven Hoggett, who had used her music in previous productions and who used her existing instrumental tracks during rehearsals of Cursed Child sequences. In an interview, Martin Lowe explained some of the rationale behind creating a distinct, unrelated musical world for the plays:

I thought whatever happens first up in the play will be the world that we give the audience, and of course they're all standing outside the theatre singing John Williams's themes, so it was very clear that our opening musical gestures better be a million miles removed from the movies [...] We were so bold with the opening, in that it didn't sound like the movie, it was a whole different aural palate, and there was no apology for it at all. Also, it wasn't like we'd made a film, they were in a totally different environment, they weren't in a theme park and they weren't in a movie, they'd gone to the theatre. ${ }^{54}$

For Lowe, and indeed the rest of the creative team, the highest priority was to create a piece of theatre in its own right, and thereby a world that is tailor-made and specifically designed to house and portray the play's narrative in the most effective way possible. Gareth Fry describes 'wanting to create a show that was unique to itself, that didn't draw off aspects of the films', and thus took a different direction in creating sounds for spells, cloaks and staircases.$^{55}$ In his words, the film sounds 'wouldn't have been right for our world. We have a different sort of magic. And a different language for telling the story [...] generally we're quite abstract and stylised in how we tell the story, and that requires a completely different language of sound from the films'. ${ }^{56}$ Both Lowe and Fry see the break from the sound world of the films as a necessity, not only due to the difference in medium and the conceptual and practical implications of this, but also for the articulation and integrity of the distinct play-world. In terms of authenticity, the play need only be authentic to itself and to Rowling's primary canon: the narrative as told in the novels.

Returning to Imogen Heap's score for the play and its articulation of a supposedly new musical world in the Harry Potter universe, it is interesting to note that the score features only one new composition, with the rest of the music being taken from Heap's extensive back catalogue. ${ }^{57}$ Many moments of the score bear little resemblance to the songs from which they are derived. In fact, one of the more climactic moments features music taken from a two-bar backing vocal buried in one of Heap's tracks that Lowe found and extended into a full piece. However, there are other moments where the song is barely altered, and indeed one instance where the lyrics are retained. One 
particular scene sees the two protagonists Albus and Scorpius travelling back in time to the Hogwarts of their fathers (Harry and Draco respectively), in order to change events at the Triwizard Tournament and hopefully prevent Cedric Diggory from being killed. Arriving into the Forbidden Forest and trying to remain unseen as they approach the castle, the song 'Hide and Seek' begins to play - a choral arrangement, and the only instance of lyrical accompaniment (the cue is entitled 'Edge of the Forest' from Suite Two of the soundtrack). ${ }^{58}$ The first words heard are 'hide and seek, trains and sewing machines, all those years, they were here first.' Considering the temporal shift to a time when their fathers were at their school and the duo's need to remain undetected, these lyrics are fairly apt. Furthermore, the song is perhaps Heap's most famous, having featured in numerous popular television programmes including a memorable killing scene in The O.C. and thence having been fashioned into an early internet meme. The song continues with the chorus: 'mmm what'd you say? Mmm that you only meant well, well - course you did', perhaps prophesying or predestining the mess that the boys make, though well-intentioned. The recognisable nature of the song here presents a conflation of two worlds - the world of Harry Potter and the world of popular music culture, and many Cursed Child audience members will be familiar with both. This is not necessarily problematic in terms of worldbuilding, but does produce some interesting effects. Many audience members, in recognition of the song, are bound to draw memories and thoughts about the song into their experience of the scene, and this leads to a multiplicity of potential interpretations by drawing on external, nonfranchise influences.

41 Pre-existing pop music has appeared in the Harry Potter films, in the form of Jarvis Cocker (Goblet of Fire) or Nick Cave and the Bad Seeds (Deathly Hallows Part One), but has never formed a part of the extra-diegetic scoring (though the Nick Cave song on the magical wireless in Deathly Hallows Part One does cross over somewhat towards the intra-diegetic). One final example from the end of the play highlights ways in which an awareness of Imogen Heap's music gives viewers a deeper understanding of the play's narrative structure. The final few minutes of Act IV are accompanied by a positive, upbeat piece of music with various interweaving melodies and countermelodies, including Imogen's trademark 'ohh' vocal (the final cue of Suite Four, entitled 'A Nice Day'). ${ }^{59}$ To the unaware, this just sounds like continuation music for the various scene changes and emotional exchanges as the characters part ways. However, those who recognise the song's chorus (and title) as '[say] Goodnight and Go' will perhaps be more aware of the play's impending closure, once again bringing the song's unheard but culturally remembered lyrics into the audience's understanding of the scene as a whole - as was the author's experience..$^{60}$

Imogen Heap herself was aware that her work on this project would constitute the coming together of two distinct realms: in an interview regarding her work on Cursed Child she stated 'it feels like a meeting of two worlds. I feel very lucky'. ${ }^{61}$ Whether or not the play's music is recognised is perhaps unimportant when compared to its effectiveness in creating a coherent world for the play to take place in. It smooths over scene changes, articulates temporal shifts, and informs the audience in much the same way as a film score: both creating a world and simultaneously suturing the audience into it, here by means of surround sound as well as musical signposting and evocative sound design. The fact that the musical and sonic worlds of Cursed Child are at most tangentially (if accidentally) related to the sound worlds of the films means that Cursed Child is only related to (and thus authentic to) the book-world - a fact strengthened by 
the casting of a black actor to play Hermione in all productions so far, as well as the aforementioned differences in pronunciation. However, the success of the play is found partly in its ability to convince audiences that these differences, musical and otherwise, do not matter. As Lowe identifies:

if you're really engaged in a show, you don't sit there thinking 'I wish we got Hedwig's Theme' [...] you do hear people saying 'it's just a shame Daniel Radcliffe isn't doing it' but then the show starts and it says 'this is Harry' and you go 'OK, it's Harry. ${ }^{62}$

\section{Conclusion}

Within these four tourist experiences music operates in a number of ways to enable different ways of inhabiting the world of Harry Potter. The two more absorptive experiences (the CineConcerts tour and the Warner Bros tour) both feature music as a way of involving the guest and heightening their experience by drawing on memory and nostalgia, invoking wonder either by foregrounding music or by sensitively pairing music with visual cues and set pieces. The more immersive experiences (the Cursed Child play and the Wizarding World attractions) both use music for its immersive qualities to great and numerous effects, most notably by building coherent worlds that give structure and form to the experiences for their duration. As detailed above, the active or passive engagement of the guest varies in each attraction from the spectatorial modes of the concert and the play to the more autonomous modes of the theme park and the studio tour, and the extent to which the experiences may be thought of as interactive also varies. Viewers whoop and cheer for their favourite characters at the Philosopher's Stone concerts, ride brooms at the Studio Tour, do 'magic' at Universal Orlando, and even the audience's laughter or applause can dictate or influence the actors' pace in Cursed Child. In each experience, music plays a key part in the imaginative engagement of the visitor - in some cases perhaps even guiding or controlling them - and thus contributes to the overall success of the attraction, whether understood as immersive or absorptive. Music has also been shown to draw in large part on the existing corpus of film scores and soundtracks, drawing on a visitor's musical memory whether through direct quotation and transplantation, or through allusion, reorchestration and extrapolation.

A fan in search of a more realistic or naturalistic experience might balk at the pervasive presence of 'non-diegetic' music in the Wizarding World theme parks, but its use arguably creates a more film-like experience by drawing on filmic memory, where spectatorial limits are more readily accepted. Rather than inciting a sense of disbelief, music in fact enables disbelief's suspension, or the 'willing activation of pretence'; ${ }^{63}$ guests are sutured into the micro-worlds of Diagon Alley and Hogsmeade in much the same way as they are when watching the films. ${ }^{64} \mathrm{~A}$ comparative experience from a different franchise provides a stark contrast to this pervasive use of music. The Lord of the Rings film set of Hobbiton in Matamata, New Zealand opened for tours in 2002, offering visitors a chance to explore the bucolic landscape of the Shire, complete with hobbit holes, mills and the Green Dragon Inn. Here, the only music to be heard on the whole set is the traditional Irish folk music played in the Green Dragon Inn, the rest of the set being filled only with naturally occurring soundscapes, resulting in a much more naturalistic experience. Visitor Simon Clayton states that the Inn's 'handcrafted round doors, Gaelic music and an open fire all sent us straight back to the films', 
pointing to a different kind of worldbuilding at play in this example of film tourism one which seeks to create a realistic manifestation of the world-of the films, rather than a more cinematic iteration of the world-in the films. ${ }^{65}$

The franchise, with its many access points and entry routes, continues to expand: a new Harry Potter touring exhibition has been recently announced and is set to arrive in 2022, promising 'best-in-class immersive design and technology [that will] honor the iconic moments, characters, settings, and beasts as seen in the films' ${ }^{6}{ }^{6}$ Music will undoubtedly feature as part of this new entry point's means of storytelling and immersive worldbuilding, and it seems likely that the designers will draw on the existing film scores in similar ways to those of the theme park or the studio tour. What is clearest here is that music is a fundamental part of each of these attractions, and plays a central role in their success by capturing or stimulating the imagination of the visitor and helping to conjure the childlike sense of wonder that keeps fans coming back for more.

\section{BIBLIOGRAPHY}

“A New Harry Potter ${ }^{\mathrm{TM}}$ Exhibition Is Coming Soon!". Imagine Exhibitions. Accessed 28 March, 2021. https://www.imagineexhibitions.com/exhibitions/harry-potter-the-exhibition

Burlingame, Jon. "Score One for Movie Maestros: Audiences Grow for Film-Music Concerts". Variety 14/11/13. Accessed on February 20, 2018. http://variety.com/2013/biz/news/score-onefor-movie-maestros-audiences-grow-for-film-music-concerts-1200827772/

Burlingame, Jon. "Live Movie Concerts A Cash Cow for Orchestras". Variety 29/4/15. Accessed on February 20, 2018. http://variety.com/2015/music/features/live-movie-concerts-a-cash-cow-fororchestras-1201483456/

Butler, David. Fantasy Cinema: Impossible Worlds on Screen. London: Wallflower, 2009.

Camp, Gregory. "Mickey Mouse Muzak: Shaping Experience Musically at Walt Disney World". Journal of the Society for American Music 11 (1), 2017, 53-69.

Clayton, Simon. "Day 163: Hobbiton to Auckland". Clexworth Adventures 16/3/17. Accessed on February 20, 2018. http://clexworth.co.uk/new-zealand/day-163-hobbiton-auckland/

Clegg, Melanie. “The Making of Harry Potter Studio Tour, Leavesden”. Madame Guillotine 26/4/12. Accessed on February 20, 2018. http:/madameguillotine.co.uk/2012/04/26/the-making-of-harrypotter-studio-tour-leavesden

Eddy, Michael S. "Warner Bros. The Making of Harry Potter, Part 3: Sound”. Live Design Online 10/10/12. Accessed on February 20, 2018. http://www.livedesignonline.com/architainment/ warner-bros-making-harry-potter-part-3-sound

"Harry Potter and the Escape from Gringotts". Internet Movie Database. Accessed on March 17, 2021. https://www.imdb.com/title/tt3731688/ 
"Harry Potter: The Making of Diagon Alley". NBC News 5/9/14. Accessed on February 20, 2018. https://www.nbcnews.com/video/harry-potter-the-making-of-diagon-alleypart-1-296086595857

Hatfield, Elaine, John T. Cacioppo, and Richard L. Rapson. Emotional Contagion: Studies in Emotion and Social Interaction. Cambridge: Cambridge University Press, 1993.

Izundu, Chi Chi. “Harry Potter Play Music 'isn't ready for album release”. BBC Newsbeat 30/7/16. Accessed on February 20, 2018. http:/www.bbc.co.uk/newsbeat/article/36933580/harry-potterplay-music-isnt-ready-for-album-release

Jaworksi, Michelle. “The Magic of Watching a 'Harry Potter' Movie Performed by a Live Orchestra”. The Daily Dot 26/6/16. Accessed on February 20, 2018. https://www.dailydot.com/ parsec/harry-potter-sorcerers-stone-live-orchestra-philadelphia-mann-center/

King, Susan. "“Lord of the Rings in Concert' Coming to Honda Center". Los Angeles Times 12/10/11. Accessed on February 20, 2018. http://articles.latimes.com/2011/oct/12/entertainment/la-etlord-rings-20111012

McConachie, Bruce. Engaging Audiences: A Cognitive Approach to Spectating at the Theatre. New York: Palgrave Macmillan, 2008.

Palm, Matthew J. "Review: Live Music Makes Harry Potter Even More Magical”. Orlando Sentinel 19/2/17. Accessed on February 20, 2018. http://www.orlandosentinel.com/entertainment/artsand-theater/the-artistic-type/os-et-mjp-philharmonic-harry-potter-20170219-story-html

Pierson, Michele. Special Effects: Still in Search of Wonder. New York: Columbia University Press, 2002.

Pine, B. Joseph II and James H. Gilmore. The Experience Economy, Boston: Harvard Business School, 2011

Rowling, J.K. “Celestina Warbeck”. Pottermore. Accessed on February 20, 2018. https:// www.pottermore.com/writing-by-jk-rowling/celestina-warbeck

Rowling, J.K. Harry Potter and the Chamber of Secrets. London: Bloomsbury, 1998.

Sabbagh, Dan. "Josh Berger on Leavesden Film Studios: Harry Potter's New Chamber of Secrets". The Guardian 10/6/12. Accessed on February 20, 2018. https://www.theguardian.com/media/ 2012/jun/10/josh-berger-warner-bros-interview

Saler, Michael. As If: Modern Enchantment and the Literary Prehistory of Virtual Reality. Oxford: Oxford University Press, 2012.

Smith, Jeff. "Unheard Melodies? A Critique of Psychoanalytic Theories of Film Music" in David Bordwell and Noël Carroll (eds.), Post-Theory: Reconstructing Film Studies, Madison, WI: University of Wisconsin Press, 1996, 230-247.

Stevens, Meghan. Music and Image in Concert: Using Images in the Instrumental Music Concert. Sydney: Music and Media, 2009.

“The Global Tour". Harry Potter in Concert. Accessed January 28, 2020. https:// www.harrypotterinconcert.com/global-tour

“The List”. PotterGlot. Accessed March 29, 2021. https://www.potterglot.net/the-list/

"The Show". Harry Potter in Concert. Accessed February 20, 2018. https://

www.harrypotterinconcert.com/about-us/ 
Todorov, Tzvetan. The Fantastic: A Structural Approach to a Literary Genre. Ithaca, NY: Cornell University Press, 1975.

Waysdorf, Abby and Stijn Reijnders. "Immersion, Authenticity and the Theme Park as Social Space: Experiencing the Wizarding World of Harry Potter'. International Journal of Cultural Studies 21(2), 2018, 173-188.

Webster, Jamie Lynn. "Creating Magic with Music: The Changing Dramatic Relationship Between Music and Magic in Harry Potter Films" in Janet K. Halfyard (ed.), The Music of Fantasy Cinema. Sheffield: Equinox, 2012, 193-217.

Webster, Jamie Lynn. "The Music of Harry Potter: Continuity and Change in the First Five Films", PhD Thesis, University of Oregon, 2009.

Wells, Nick and Mark Fahey. "Harry Potter and the \$25 Billion Franchise”. CNBC 13/10/16. Accessed February 20, 2018. https://www.cnbc.com/2016/10/13/harry-potter-and-the-25billion-franchise.html

White, Daniel. "One Does Not Simply Walk Into Mordor: Sound and Music as Suture in the Opening Sequences of Peter Jackson's Middle-earth Films". Music, Sound and the Moving Image 14(2), 2020, 93-117.

White, Daniel. "The Music of Fantasy Film: On the Creation, Evolution and Inhabitation of Musical Worlds". PhD Thesis, University of Manchester, 2018.

Winters, Ben. "The Non-Diegetic Fallacy: Film, Music, and Narrative Space”, Music and Letters 91 (2), 2010.

Yacavone, Daniel. Film Worlds: A Philosophical Aesthetics of Cinema. New York: Columbia University Press, 2014.

\section{NOTES}

1. Nick Wells \& Mark Fahey, "Harry Potter and the $\$ 25$ Billion Franchise", CNBC, October $13^{\text {th }}$, 2016.

2. "The List", PotterGlot, <accessed 29/3/21>.

3. Michele Pierson, Special Effects: Still in Search of Wonder (New York: Columbia University Press, 2002), 168.

4. David Butler, Fantasy Cinema: Impossible Worlds on Screen (London: Wallflower, 2009), 34-36, and Angela Ndalianis, Neo-Baroque Aesthetics and Contemporary Entertainment (London: MIT Press, 2004), 28.

5. Tzvetan Todorov, The Fantastic: A Structural Approach to a Literary Genre (Ithaca, NY: Cornell University Press, 1975).

6. Michael Saler, As If: Modern Enchantment and the Literary Prehistory of Virtual Reality (Oxford: Oxford University Press, 2012).

7. Daniel Yacavone, Film Worlds: A Philosophical Aesthetics of Cinema (New York: Columbia University Press, 2014), 40.

8. This is a simplification of Winters' theory which makes a strong case for this more fluid and less clinical understanding of so-called 'non-diegetic' music. See Ben Winters, "The Non-Diegetic Fallacy: Film, Music, and Narrative Space”, Music and Letters 91 (2), 2010, 237.

9. B. Joseph Pine II \& James H. Gilmore, The Experience Economy (Boston: Harvard Business School, 2011), 46.

10. "The Show" from Harry Potter in Concert website <accessed on February 20, 2018>. 
11. Jon Burlingame, "Score One for Movie Maestros: Audiences Grow for Film-Music Concerts", Variety 14/11/13 <accessed on February 20, 2018>, and "Live Movie Concerts A Cash Cow for Orchestras", Variety 29/4/15 <accessed on February 20, 2018>.

12. Susan King, “'Lord of the Rings in Concert' Coming to Honda Center", Los Angeles Times 12/10/11 <accessed February 20, 2018>.

13. "The Global Tour" from Harry Potter in Concert website <accessed on February 20, 2018>.

14. See Elaine Hatfield, John T. Cacioppo and Richard L. Rapson, Emotional Contagion: Studies in Emotion and Social Interaction (Cambridge: Cambridge University Press, 1993) and Bruce McConachie, Engaging Audiences: A Cognitive Approach to Spectating at the Theatre (New York: Palgrave Macmillan, 2008).

15. Andrew P. Alderete, publicist for CineConcerts, confirmed via email correspondence on $6^{\text {th }}$ April 2014 that these announcements take place at every concert.

16. There is an interesting mixing of worlds that takes place at these concerts. Alongside audience cheers for the appearance of certain characters, there is also applause for the orchestra after the prologue, after the first half, and other more distinct movements - a musical convention that serves momentarily to refocus attention on the hardworking orchestra rather than the images behind them. Other audience reactions convey a knowledge or understanding from outside the wizarding world. Applause for the appearance of wandmaker Garrick Ollivander, played by John Hurt, might seem disproportionately loud for such a minor role, were it not for the fact that Hurt died in early 2017. In a similar vein, the loudest cheers at the Manchester concert attended by the author went to the late Alan Rickman's character, Severus Snape, despite the fact that throughout this film he is depicted as the villain. This shows not only a great love and respect for the actor who died in 2016, but also an awareness of Snape's true allegiance to Harry and his sacrificial role in the grander narrative.

17. See Meghan Stevens, Music and Image in Concert: Using Images in the Instrumental Music Concert, (Sydney: Music and Media, 2009), 72.

18. Jeff Smith, "Unheard Melodies? A Critique of Psychoanalytic Theories of Film Music" in PostTheory: Reconstructing Film Studies, ed. David Bordwell and Noël Carroll (Madison, WI: University of Wisconsin Press, 1996) 230-247, 239.

19. Matthew J. Palm, "Review: Live Music Makes Harry Potter Even More Magical" in Orlando Sentinel 19/2/17 <accessed February 20, 2018>.

20. Michelle Jaworksi, "The Magic of Watching a 'Harry Potter' Movie Performed by a Live Orchestra", The Daily Dot 26/6/16 <accessed February 20, 2018>.

21. Dan Sabbagh, "Josh Berger on Leavesden Film Studios: Harry Potter's New Chamber of Secrets", The Guardian 10/6/12 <accessed on February 20, 2018>.

22. Hedwig's Theme, <accessed July 13, 2021>.

23. Kari Rae Seekins, Skype interview with author, $3^{\text {rd }}$ April 2016.

24. Entry Into The Great Hall And The Banquet, <accessed July 13, 2021>.

25. Diagon Alley and the Gringotts Vault, <accessed July 13, 2021>.

26. Colbert Davis, Skype interview with author, $18^{\text {th }}$ April 2016.

27. The Flying Car, <accessed July 13, 2021>, A Journey To Hogwarts, <accessed July 13, 2021>.

28. Melanie Clegg, "The Making of Harry Potter Studio Tour, Leavesden", Madame Guillotine 26/4/12 <accessed February 20, 2018>.

29. Harry In Winter, <accessed July 13, 2021>, Hogwarts Hymn, <accessed July 13, 2021>.

30. Seekins, interview.

31. Jamie Lynn Webster, "The Music of Harry Potter: Continuity and Change in the First Five Films", PhD Thesis, University of Oregon, 2009. See also Daniel White, "The Music of Fantasy Film: On the Creation, Evolution and Inhabitation of Musical Worlds", PhD Thesis, University of Manchester, 2018. 
32. Michael S. Eddy, "Warner Bros. The Making of Harry Potter, Part 3: Sound", Live Design Online 10/10/12 <accessed February 20, 2018>.

33. Seekins, interview.

34. Dumbledore's Army, <accessed July 13, 2021>.

35. Wizard Wheezes, <accessed July 13, 2021>.

36. Dumbledore's Farewell, <accessed July 13, 2021>, Severus and Lily, <accessed July 13, 2021>.

37. Harry and Hermione, <accessed July 13, 2021>, Snape and the Unbreakable Vow, <accessed July $13,2021>$.

38. In the case of the author's own research trips, he had visited the Studio Tour in Leavesden just prior to visiting the Wizarding World in Orlando, and the use of 'Harry in Winter' in the Hogsmeade area of the theme park did remind him of his previous experience of seeing the Hogwarts model up close, creating a powerfully nostalgic experience.

39. Voice likeness actors and archive material were also used to portray Harry and Hermione in the ride films, as Daniel Radcliffe and Emma Watson were unavailable at the time of filming. See "Harry Potter and the Escape from Gringotts", Internet Movie Database <accessed March 17, 2021>.

40. Jamie Lynn Webster, "Creating Magic with Music: The Changing Dramatic Relationship Between Music and Magic in Harry Potter Films" in The Music of Fantasy Cinema, ed. Janet K. Halfyard, (Sheffield: Equinox, 2012), 193-217, 200. This theme is heard throughout The Face of Voldemort, <accessed July 13, 2021>.

41. Reunion of Friends, from 4:22 to the end, <accessed July 13, 2021>.

42. This cue can be heard from 4:16 in Hogwarts Express train full ride POV - Diagon Alley to Hogsmeade at Universal Orlando, <accessed July 13, 2021>.

43. J. K. Rowling, Harry Potter and the Chamber of Secrets (London: Bloomsbury, 1998), 35.

44. J. K. Rowling, "Celestina Warbeck", Pottermore, <accessed February 20, 2018>.

45. "Harry Potter: The Making of Diagon Alley", NBC News 5/9/14 <accessed February 20, 2018>.

46. "Harry Potter: The Making of Diagon Alley", NBC News 5/9/14 <accessed February 20, 2018>.

47. Abby Waysdorf \& Stijn Reijnders, "Immersion, Authenticity and the Theme Park as Social Space: Experiencing the Wizarding World of Harry Potter", International Journal of Cultural Studies 21(2), 173-188, 182.

48. Gregory Camp, "Mickey Mouse Muzak: Shaping Experience Musically at Walt Disney World”, Journal of the Society for American Music 11 (1), 2017, 53-69.

49. Waysdorf \& Reijnders, "Immersion, Authenticity and the Theme Park as Social Space", 175.

50. Winters, "The Non-Diegetic Fallacy", 231.

51. Camp, "Mickey Mouse Muzak", 62-63, and Saler, As If, 30-32.

52. Lily's Theme, <accessed July 14, 2021>.

53. Suite Three: Expecto Patronum, <accessed July 14, 2021>.

54. Martin Lowe, Skype interview with author, $9^{\text {th }}$ November 2016.

55. Gareth Fry, email correspondence with author, $13^{\text {th }}$ January 2017.

56. Gareth Fry, email correspondence with author, $13^{\text {th }}$ January 2017.

57. Lowe, interview.

58. Suite Two: Edge of the Forest, <accessed July 14, 2021>.

59. Suite Four: A Nice Day, <accessed July 14, 2021>.

60. Goodnight and Go, <accessed July 14, 2021>.

61. Chi Chi Izundu, "Harry Potter Play Music 'isn't ready for album release”, BBC Newsbeat 30/7/16 <accessed February 20, 2018>.

62. Lowe, interview.

63. Saler, As If, 30-32.

64. See Daniel White, "One Does Not Simply Walk Into Mordor: Sound and Music as Suture in the Opening Sequences of Peter Jackson's Middle-earth Films", Music, Sound and the Moving Image 14(2), 93-117. 
65. Simon Clayton, "Day 163: Hobbiton to Auckland", Clexworth Adventures 16/3/17 <accessed February 20, 2018>.

66. “A New Harry Potter ${ }^{\mathrm{TM}}$ Exhibition Is Coming Soon!", Imagine Exhibitions <accessed 28 March, 2021>.

\section{ABSTRACTS}

This article analyses the use of music and sound at four distinct attractions related to the Harry Potter franchise. As extensions of a transmedial world derived in large part from the film series as well as the novels, each of these tour sites uses music and sound in distinct ways, drawing on or extending the musical worlds of the films, or creating worlds of their own. A close analysis of these musical worlds gives us a deeper understanding of the operation and function of the attractions, which are theorised as immersive or absorptive in different ways, and in which visitors are given differing levels of agency in directing their experience. Music is shown to draw variously on motivic memory and nostalgia, heightening or intensifying emotional connections and in each case enabling the imaginative inhabitation of a fantasy world.

\section{INDEX}

Keywords: Harry Potter, film tourism, music, sound, worldbuilding

\section{AUTHOR}

\section{DANIEL WHITE}

Daniel White is a lecturer in musicology at the University of Huddersfield, where he teaches film music, pop musicology, performance and research skills. Much of his research focuses on music and worldbuilding in the fantasy film franchise and the various transmedial ways in which music enables the imaginative inhabitation of fantasy worlds. His forthcoming monograph on Fantasy Film Music will be published as part of the Ashgate Screen Music series.

University of Huddersfield 